\title{
REPRESENTASI ANTI DISKRIMINASI PADA FILM KARTUN 3D ZOOTOPIA (KAJIAN SEMIOTIKA ROLAND BARTHES)
}

\author{
Ali Muqoddas ${ }^{1}$, Noor Hasyim ${ }^{2}$ \\ ${ }^{1,2}$ Progdi Desain Komunikasi Visual, \\ Fakultas IImu Komputer, Universitas Dian Nuswantoro \\ 12ali.muqoddas@gmail.com, ${ }^{2}$ hasyim.nahl@gmail.com
}

\begin{abstract}
Abstrak
Isu diskriminasi SARA seperti tiada habisnya terjadi di dunia ini, begitu juga di Indonesia. Hal ini mengakibatkan tema-tema tentang SARA menjadi sensitif ketika dibahas atau pun difilmkan. Hal ini mengakibatkan jarang ditemui film yang mengangkat tentang SARA. Lain halnya dengan Walt Disney. Walt Disney baru-baru ini merilis film kartun 3D yang mengangkat tema anti diskriminasi SARA yang berjudul Zootopia. Film ini menjadi menarik karena isu diskriminasi SARA yang diangkat dibalut dengan konsep yang kreatif hingga sensivitas isu SARA tersebut menjadi berkurang. Representasi anti diskriminasi SARA pada film Zootopia ini selanjutnya dikaji dengan metode semiotika Roland Barthes dengan pendekatan deskriptif kualitatif. Berdasarkan dari analisis, dapat disimpulkan bahwa film Zootopia memuat pesan ideologi tentang anti diskriminasi SARA bahwa kedudukan manusia dimata manusia yang lain pada hakikatnya adalah sama. Setiap manusia berhak dan wajib memperlakukan dan diperlakukan secara bijak tanpa memperdulikan background asal manusia itu sendiri. Penghargaan pada setiap individu tidak didasarkan pada faktor keturunan, ras, suku ataupun agama, namun didasarkan pada prestasi dari individu itu sendiri.
\end{abstract}

Kata Kunci: diskriminasi SARA, Zootopia, Roland Barthes

\begin{abstract}
The issue of racial discrimination as an endless happen in this world, so also in Indonesia. This resulted in the themes of SARA be sensitive when discussed or filmed. This resulted in a rare film that raised about SARA. Another case with Walt Disney. Walt Disney recently released 3D animated film that mengangat theme of anti-discrimination SARA entitled Zootopia. This film is interesting because racial discrimination issues raised wrapped with a creative concept to the sensitivity of the racial issues be reduced. SARA anti-discrimination representation on film Zootopia is further studied with Roland Barthes semiotic methods with qualitative descriptive approach. Based on the analysis, it can be concluded that the film contains Zootopia ideology of anti-discrimination message SARA that the position of human eyes of another human being is essentially the same. Every human being is entitled and obliged to treat and be treated wisely, regardless of the origin of man's own background. On each individual award is not based on heredity, race, ethnicity or religion, but is based on the achievements of the individuals themselves.
\end{abstract}

Keywords: racial discrimination, Zootopia, Roland Barthes 


\section{PENDAHULUAN}

Dalam Kamus Besar Bahasa Indonesia telah didefinisikan bahwa diskriminasi adalah pembedaan perlakuan terhadap sesama warga negara (berdasarkan warna kulit, golongan, suku, ekonomi, agama, dan sebagainya). Diskriminasi bisa terjadi tanpa adanya prasangka dan sebaliknya seseorang yang berprasangka juga belum tentu akan mendiskriminasikan (Duffy \& Wong, 1996).

Sudah menjadi pemahaman umum bahwa manusia di bumi ini terdiri dari keaneragaman Ras Agama Suku dan Antar golongan (SARA). Namun, karena sifat keegoisan manusia, perbedaan tersebut tak dipungkiri sering menimbulkan perilaku diskriminasi di berbagai daerah atau negara. Perilaku diskriminasi ini sudah menjadi isu umum hampir di setiap negara dan daerah dari dulu hingga sekarang.

Beberapa contoh perilaku diskriminasi SARA di berbagai negara seperti tiada habisnya. Seperti yang terjadi sejak zaman perang dunia kedua yaitu kekejaman tentara Nazi di era Hitler, lalu seperti kasus diskriminasi kulit hitam di Afsel dengan politik Apartheidnya, hingga beberapa kasus yang terjadi di tahun belakangan seperti yang terjadi di Prancis pada tahun 2010 hingga 2014 yang melakukan pendeportasian secara besarbesaran etnis Roma ke Negara asalnya setelah Prancis bekerja sama dengan Rumania (Elvina dan I Made, 2015). Di Amerika, diskriminasi ras kulit putih dan kulit hitam juga masih menjadi isu hangat hingga saat ini. Seperti pada kasus Kematian Freddie Gray remaja kulit hitam berusia 25 akibat kekerasan dalam tahanan polisi Baltimore pada Mei 2015 yang lalu (BBC.com, 1 Mei 2015).

Tak hanya di Eropa dan Amerika, di Indonesia pun tak bisa terhindar dari isu diskriminasi SARA. Terlebih kondisi masyarakat Indonesia yang multikultur dan agama membuat isu diskriminasi SARA sepertinya akan terus ada di Indonesia. Contoh kelam kasus diskriminasi SARA Indonesia seperti yang masih hangat di ingatan kita, kasus penyerangan masjid di Tolikora Papua dan pembakaran 2 Gereja di Purworejo pada Juli 2015 yang lalu. Selain itu pada Oktober 2015 juga terjadi pembakaran gereja di Kabupaten Aceh Singkil (Okezone.com, 20 Oktober 2015). Tak hanya itu, akhir-akhir ini isu diskriminasi SARA juga sering mencuat di setiap pagelaran Pemilu baik daerah maupun pemilu presiden. Hal ini seolah-olah memunculkan anggapan bahwa selama masih ada perbedaan SARA di dunia ini, maka diskriminasi SARA pun juga akan selalu terjadi pada masyarakat di seluruh dunia.

Beberapa fakta di atas menyebabkan tema-tema berbau SARA menjadi topik yang menakutkan untuk dibicarakan ataupun juga diperfilmkan pada layar perfilman dunia. Tema SARA menjadi tema yang sensitif yang seakan tidak boleh tersentuh dikalangan masyarakat dunia karena ditakutkan akan memunculkan pergolakan baru di masyarakat. Hal ini menjadi salah satu alasan masih sedikitnya film-film yang mengangkat isu SARA, sehingga justru film bertemakan superhero dan action yang akhir-akhir ini sering bermunculan. Film kartun menjadi salah satu alternatif untuk dapat diangkat berkenaan dengan topik anti diskriminasi SARA tersebut. G. Sasongko dalam bukunya yang berjudul Kartun sebagai Media Dakwah, mendefinisikan bahwa 
kartun merupakan pencerminan ciri-ciri kemanusiaan pada umumnya secara karikatural (Sasongko, 2005: 9).

Walt Disney sebagai salah satu studio pengembang film kartun ternama di dunia mencoba memanfaatkan situasi ini. Walt Disney baru-baru ini telah merilis sebuah film kartun 3D yang mengangkat topik SARA atau lebih tepatnya anti diskriminasi SARA dengan judul Zootopia. Zootopia merupakan film Kartun 3D bertema anti diskriminasi SARA yang disajikan secara menarik dan kreatif. Untuk menghindari pergolakan di masyarakat mengingat sensitifnya topik SARA ini, Anti diskriminasi SARA dalam film Zootopia ini diilustrasikan melalui sebuah cerita tentang keaneragaman hewan yang dapat hidup rukun dan bahagia di sebuah kota bernama Zootopia. Konflik SARA yang dimunculkan pada film tersebut sama sekali tidak dihubungkan dengan tema-tema SARA yang selama ini sangat sensitif di mata masyarakat. Dalam film Zootopia ini, diskriminasi SARA diilustrasikan melalui adanya konflik perbedaan antara binatang predator (pemangsa) dengan binatang mangsa.

Selanjutnya, untuk dapat menyimpulkan pesan ideologi yang terkandung dalam film zootopia ini, akan digunakan metode semiotika Roland Barthes dalam memaknai beberapa scene yang dapat mewakili pesan anti diskriminasi SARA pada film tersebut. Menurut Barthes, semiology hendak mempelajari bagaimana kemanusiaan (humanity) memaknai hal (things). Barthes menganggap kehidupan sosial sebagai sebuah signifinaksi. Dengan kata lain, kehidupan sosial, apapun bentuknya merupakan suatu sistem tanda tersendiri (Kurniawan, 2001: 53).

Teori semiotik Barthes hampir secara harfiah diturunkan dari teori bahasa menurut de Saussure. Sebagaimana pandangan Saussure, Barthes juga meyakini bahwa hubungan antara penanda dan pertanda terbentuk secara arbiter. Namun, bila Saussure hanya menekankan pada pandangan dalam tataran denotatif, Barthes menyempurnakan semiologi Saussure dengan mengembangkan sistem penandaan pada tingkat konotatif (Nawiroh Vera, 2014: 27). Dengan menggunakan metode semiotika Roland Barthes ini, diharapkan representasi diskriminasi SARA dalam film Zootopia ini dapat tergambarkan dengan jelas, sehingga dapat dimengerti bagaimana pesan ideologi film ini dapat tersampaikan dengan baik kepada penonton.

\section{METODE PENELITIAN}

Dalam melakukan penelitian ini, penulis menggunakan metode semiotika Roland Barthes dengan pendekatan deskriptif kualitatif. Penelitian kualitatif merupakan penelitian yang digunakan untuk meneliti pada kondisi objek alamiah dimana peneliti merupakan instrumen kunci (Sugiyono, 2005). Dalam mencari hubungan, membandingkan dan menemukan pola yang merepresentasikan anti diskriminasi SARA pada film Zootopia ini, penulis menggunakan teori semiotika Roland Barthes untuk selanjutnya dideskripsikan dan diambil kesimpulan tentang pesan ideologi anti diskriminasi SARA yang disampaikan dalam film tersebut. Film Zootopia ini dianalisis melalui dua tahapan, yaitu analisis tataran pertama (denotatif) dan dilanjutkan dengan analisis tataran kedua (konotatif). 


\section{HASIL DAN PEMBAHASAN}

Setelah menonton dan menelaah lebih dalam mengenai film Animasi Zootopia ini maka penulis menemukan gambar/potongan-potongan gambar dalam film tersebut yang menunjukkan adanya representasi anti diskriminasi SARA sebagai berikut:

1. Gambar 1: Pengukuhan Judy Hops sebagai polisi kelinci pertama

2. Gambar 2: Beberapa jenis hewan keluar dari kereta api

3. Gambar 3: Kota Zootopia tampak atas

4. Gambar 4: Terlihat singa dan jerapah berdampingan setelah turun dari kereta

5. Gambar 5: Sesi pembagian tugas kepada para polisi yang berasal dari bermacammacam jenis hewan

6. Gambar 6: Hops, Nick, landak dan sekumpulan sapi yang sedang menyeberang jalan

7. Gambar 7: Judy Hops masuk di area kota tikus

8. Gambar 8: Sekelompok kukang yang sedang bekerja di DMV sebuah departemen kepengurusan mobil mamalia

9. Gambar 9: Mr. Big (bangsa tikus), bos penjahat paling ditakuti di Tundratown

10. Gambar 10: Pesta pernikahan putri Mr. Big yang diawasi para pengawalnya beruang kutub

11. Gambar 11: Gideon Grey's datang dengan membawa roti untuk Hops

12. Gambar 12: Hops dan Nick yang saling hormat setelah Nick dilantik menjadi polisi

\subsection{Analisis Semiotika Roland barthes}

Film Zootopia merupakan film animasi yang memuat pesan anti diskriminasi SARA yang sangat kuat. Di sini, analisis terbagi menjadi 2 tahapan yaitu analisis tataran pertama (denotatif) dan analisis tataran kedua (konotatif). Beberapa scene merepresentasikan bagaimana pesan anti diskriminasi SARA disampaikan dalam film tersebut. Representasi anti diskriminasi SARA dapat terlihat dalam berbagai gambar dan dialog pada film tersebut.

Tabel 1. Analisis Tataran Pertama Semiotika Roland Barthes

\begin{tabular}{|c|c|c|}
\hline Shot & Dialog/suara/teks & Visual \\
\hline \multirow[t]{4}{*}{$\begin{array}{l}\text { Full } \\
\text { Shot }\end{array}$} & $\begin{array}{l}\text { Lionheart: "Petugas } \\
\text { kelinci pertama } \\
\text { kepolisian Zootopia... } \\
\text { Judy Hops" } \\
\text { Lionheart: "Wakil } \\
\text { Walikota Bellwether, } \\
\text { lencananya" }\end{array}$ & Wakil Wallikota Bellwether, lencananya. \\
\hline & $\begin{array}{l}\text { Bellwether: "Ya, } \\
\text { terima kasih" }\end{array}$ & $\begin{array}{c}\text { Gambar 1. Pengukuhan Judy Hops sebagai polisi kelinci } \\
\text { pertama }\end{array}$ \\
\hline & Penanda & Pertanda \\
\hline & $\begin{array}{l}\text { Gambar Walikota } \\
\text { Lionheart, wakil } \\
\text { Walikota Bellwether } \\
\text { dan Judy Hops di atas }\end{array}$ & $\begin{array}{l}\text { Setelah Walikota Lionheart mengumumkan Judy } \\
\text { Hops dilantik menjadi polisi kelinci pertama, dia } \\
\text { menyuruh wakilnya Bellwether (setengah } \\
\text { mengagetkan) untuk menyematkan lencana }\end{array}$ \\
\hline
\end{tabular}




\begin{tabular}{|c|c|c|}
\hline & panggung & $\begin{array}{l}\text { kepolisian kepada Judy Hops yang sudah siap } \\
\text { menerima lencana. Bellwether sedikit kaget karena } \\
\text { dia masih kegirangan karena yang dilantik menjadi } \\
\text { polisi adalah seekor kelinci yang notabene masih } \\
\text { satu golongan dengan dirinya yaitu golongan hewan } \\
\text { mangsa. Hal tersebut dia sampaikan setelah dia } \\
\text { menyematkan lencana kepolisian kepada Hops }\end{array}$ \\
\hline Shot & Dialog/suara/teks & Visual \\
\hline \multirow[t]{3}{*}{$\begin{array}{l}\text { Full } \\
\text { Shot }\end{array}$} & $\begin{array}{l}\text { Suara pintu kereta } \\
\text { terbuka dan suara } \\
\text { langkah para } \\
\text { penumpang yang } \\
\text { sedang keluar dari } \\
\text { kereta }\end{array}$ & Gambar 2. Beberapa jenis hewan keluar dari kereta api \\
\hline & Penanda & Pertanda \\
\hline & $\begin{array}{l}\text { Gambar bermacam } \\
\text { hewan keluar dari } \\
\text { kereta }\end{array}$ & $\begin{array}{l}\text { Beberapa hewan keluar dari kereta setelah sampai } \\
\text { di stasiun Bunnyburrow (stasiun di daerah asal } \\
\text { Hops). Dalam gambar tersebut tampak pada kereta } \\
\text { terdapat banyak pintu dengan ukuran yang } \\
\text { bermacam-macam sesuai dengan ukuran tubuh } \\
\text { para hewan yang naik kereta tersebut menunjukkan } \\
\text { bahwa kereta tersebut memuat bermacam-macam } \\
\text { hewan dari spesies hewan kecil hingga besar }\end{array}$ \\
\hline Shot & Dialog/suara/teks & Visual \\
\hline \multirow[t]{3}{*}{$\begin{array}{l}\text { Extreme } \\
\text { Long } \\
\text { Shot } \\
\text { Bird Eye }\end{array}$} & $\begin{array}{l}\text { Suara } \quad \text { musik } \\
\text { (soundtrack zootopia) }\end{array}$ & \\
\hline & Penanda & Pertanda \\
\hline & $\begin{array}{l}\text { Gambar penampakan } \\
\text { kota Zootopia full } \\
\text { dari atas }\end{array}$ & $\begin{array}{l}\text { Pemandangan kota Zootopia dari ketinggian, } \\
\text { tampak ada } 4 \text { ekosistem berbeda didalamnya, yaitu } \\
\text { ekosistem perkotaan, padang pasir, padang es dan } \\
\text { ekosistem hutan belantara. Ini menunjukkan } \\
\text { Zootopia merupakan sebuah kota tempat hidup } \\
\text { banyak hewan dengan aneka ragam ekosistem }\end{array}$ \\
\hline
\end{tabular}




\begin{tabular}{|c|c|c|}
\hline Shot & Dialog/suara/teks & Visual \\
\hline \multirow[t]{4}{*}{$\begin{array}{c}\text { Medium } \\
\text { Shot }\end{array}$} & $\begin{array}{l}\text { Suara musik } \\
\text { (soundtrack zootopia) }\end{array}$ & \\
\hline & & $\begin{array}{c}\text { Gambar 4. Terlihat singa dan jerapah berdampingan setelah } \\
\text { turun dari kereta }\end{array}$ \\
\hline & Penanda & Pertanda \\
\hline & $\begin{array}{l}\text { Gambar seekor singa } \\
\text { dan jerapah yang } \\
\text { berdampingan saat } \\
\text { naik escalator }\end{array}$ & $\begin{array}{l}\text { Seekor singa yang sedang memainkan gadget yang } \\
\text { berdampingan dengan Jerapah saat naik eskalator } \\
\text { di sebuah stasiun yang megah dan modern, setelah } \\
\text { sebelumnya keduanya turun dari kereta }\end{array}$ \\
\hline Shot & Dialog/suara/teks & Visual \\
\hline \multirow[t]{4}{*}{$\begin{array}{c}\text { Medium } \\
\text { Shot }\end{array}$} & $\begin{array}{l}\text { Suara para anggota } \\
\text { polisi menggebrak- } \\
\text { gebrak meja } \\
\text { menyambut kepala } \\
\text { kepolisian yang } \\
\text { datang }\end{array}$ & 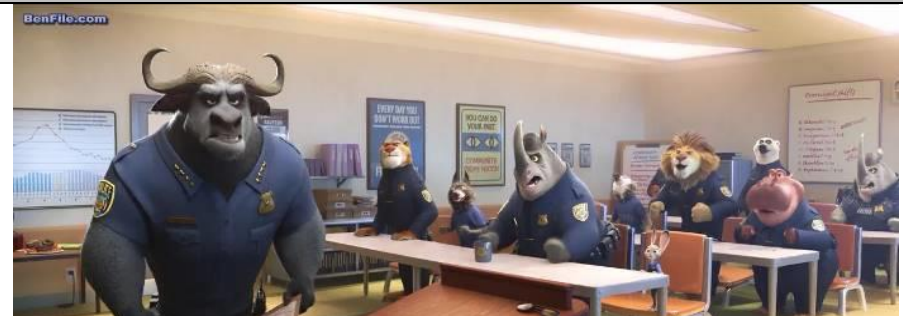 \\
\hline & & $\begin{array}{c}\text { Gambar } 5 . \text { Sesi pembagian tugas kepada para polisi yang } \\
\text { berasal dari bermacam-macam jenis hewan }\end{array}$ \\
\hline & Penanda & Pertanda \\
\hline & $\begin{array}{l}\text { Gambar kedatangan } \\
\text { kepala polisi di ruang } \\
\text { pembagian tugas } \\
\text { yang disambut } \\
\text { dengan gebrakan } \\
\text { meja para anggota } \\
\text { polisi yang lain } \\
\end{array}$ & $\begin{array}{l}\text { Seorang kepala polisi spesies banteng bernama } \\
\text { Kepala Bogo datang di ruang pembagian tugas dan } \\
\text { disambut para anggota polisi yang lain yang } \\
\text { merupakan spesies hewan yang bermacam-macam, } \\
\text { ada harimau, badak, rubah, singa, kuda nil, beruang } \\
\text { kutub, gajah dan hops si kelinci. }\end{array}$ \\
\hline Shot & Dialog/suara/teks & Visual \\
\hline $\begin{array}{c}\text { Long } \\
\text { Shot } \\
\text { Bird Eye }\end{array}$ & $\begin{array}{l}\text { Nick: "Kau tidak bisa } \\
\text { menyentuhku, } \\
\text { wortel. Aku } \\
\text { melakukan ini sejak } \\
\text { lahir" } \\
\text { Hops: "Jangan sebut } \\
\text { aku wortel" } \\
\text { Nick: "Salahku, aku } \\
\text { langsung menduga }\end{array}$ & 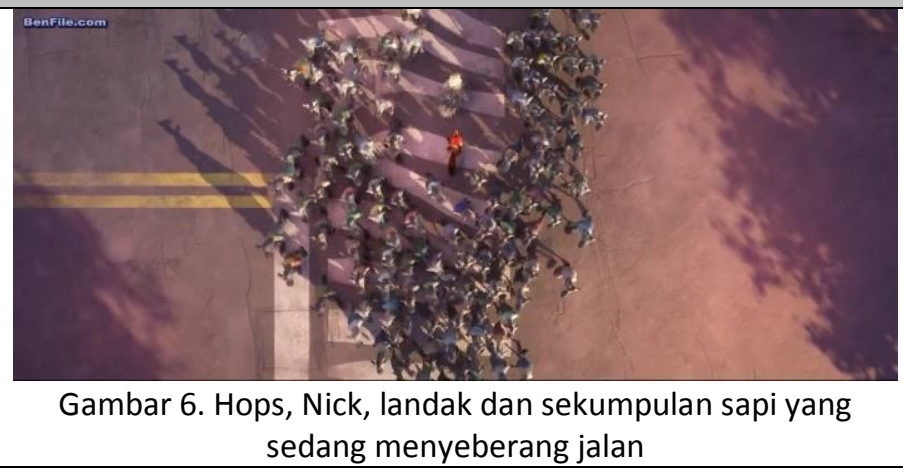 \\
\hline
\end{tabular}




\begin{tabular}{|c|c|c|}
\hline & $\begin{array}{l}\text { kau berasal dari } \\
\text { Podunk, benar? } \\
\text { Hops: Tidak, Podunk } \\
\text { ada di Deerbrooke } \\
\text { Country, dan aku } \\
\text { tumbuh di } \\
\text { Bunnyburrow }\end{array}$ & \\
\hline & Penanda & Pertanda \\
\hline & $\begin{array}{l}\text { Gambar Nick dan } \\
\text { Hops yang sedang } \\
\text { berbincang-bicang } \\
\text { menyeberang jalan di } \\
\text { belakang Landak dan } \\
\text { bersimpangan } \\
\text { dengan sekumpulan } \\
\text { sapi yang juga sedang } \\
\text { menyeberang jalan }\end{array}$ & $\begin{array}{l}\text { Nick yang sedang berbicara dengan Hops, berjalan } \\
\text { menyeberang jalan di belakang seekor landak di } \\
\text { zebra cross. Dari arah berlawanan, ada } \\
\text { segerombolan sapi yang juga sedang berjalan } \\
\text { menyeberang jalan dengan menghindar dan seperti } \\
\text { mempersilakan dan memberi jalan landak untuk } \\
\text { jalan }\end{array}$ \\
\hline Shot & Dialog/suara/teks & Visual \\
\hline \multirow[t]{3}{*}{$\begin{array}{l}\text { Long } \\
\text { Shot }\end{array}$} & $\begin{array}{l}\text { Suara riuh aktivitas } \\
\text { kampung tikus }\end{array}$ & Gambar 7. Judy Hops masuk di area kota tikus \\
\hline & Penanda & Pertanda \\
\hline & $\begin{array}{l}\text { Gambar Hops } \\
\text { terkejut ditengah- } \\
\text { tengah } \\
\text { perkampungan tikus } \\
\text { yang kecil }\end{array}$ & $\begin{array}{l}\text { Hops dalam perjalanannya mengejar maling } \\
\text { terkejut ketika ternyata dia masuk di } \\
\text { perkampungan tikus yang serba kecil hingga } \\
\text { akhirnya dia sangat berhati-hati karena takut akan } \\
\text { menginjak para tikus. Terlihat perkampungan tikus } \\
\text { tersebut merupakan sebuah perkampungan yang } \\
\text { modern, bersih dan damai }\end{array}$ \\
\hline Shot & Dialog/suara/teks & Visual \\
\hline $\begin{array}{l}\text { Long } \\
\text { Shot }\end{array}$ & $\begin{array}{l}\text { Hops: "Tunggu, } \\
\text { mereka semua } \\
\text { kukang? }\end{array}$ & 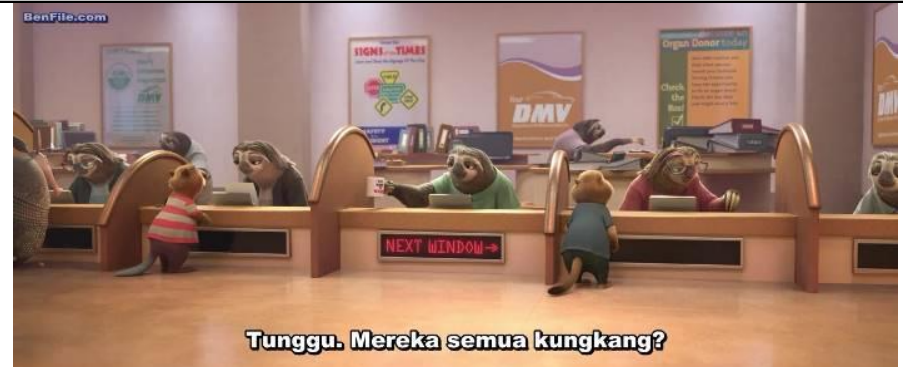 \\
\hline & & $\begin{array}{c}\text { Gambar 8. Sekelompok kukang yang sedang bekerja di DMV } \\
\text { sebuah departemen kepengurusan mobil mamalia }\end{array}$ \\
\hline
\end{tabular}




\begin{tabular}{|c|c|c|}
\hline & Penanda & Pertanda \\
\hline & $\begin{array}{l}\text { Gambar para spesies } \\
\text { kukang yang sedang } \\
\text { melayani customer di } \\
\text { DMV }\end{array}$ & $\begin{array}{l}\text { Semua petugas DMV, sebuah Departemen } \\
\text { Kepengurusan Mobil Mamalia di Zootopia } \\
\text { merupakan spesies kukang. Sebagaimana hewan } \\
\text { kukang aslinya, pergerakan kukang dalam film in } \\
\text { juga lambat dan bahkan sangat lambat, sehingga } \\
\text { pelayanan di DMV pun menjadi lambat, akhirnya } \\
\text { mengakibatkan antrian panjang. }\end{array}$ \\
\hline Shot & Dialog/suara/teks & Visual \\
\hline \multirow[t]{3}{*}{$\begin{array}{l}\text { Full } \\
\text { Shot }\end{array}$} & & \\
\hline & Penanda & Pertanda \\
\hline & $\begin{array}{l}\text { Gambar Mr. Big yang } \\
\text { sedang duduk }\end{array}$ & $\begin{array}{l}\text { Mr. Big merupakan seekor tikus yang merupakan } \\
\text { bos penjahat, dan paling ditakuti di Tundratown. } \\
\text { Paling ditakuti karena dia tak segan-segan akan } \\
\text { membekukan setiap hewan yang dimusuhinya. }\end{array}$ \\
\hline Shot & Dialog/suara/teks & Visual \\
\hline \multirow[t]{3}{*}{$\begin{array}{l}\text { Full } \\
\text { Shot }\end{array}$} & $\begin{array}{l}\text { Suara musik pesta } \\
\text { pernikahan putri Mr. } \\
\text { Big }\end{array}$ & 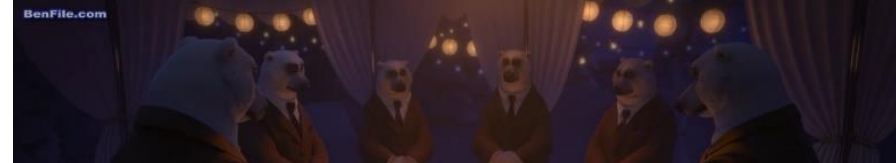 \\
\hline & Penanda & Pertanda \\
\hline & $\begin{array}{l}\text { Gambar pesta } \\
\text { pernikahan Mr. Big } \\
\text { dan beberapa } \\
\text { Beruang Kutub } \\
\text { berdiri }\end{array}$ & $\begin{array}{l}\text { Pesta pernikahan anak Mr. Big beserta para tikus } \\
\text { lainnya di atas sebuah meja bundar dengan } \\
\text { penjagaan ketat para anak buahnya dari spesies } \\
\text { beruang kutub yang besar dan gagah dengan } \\
\text { berpakaian jas rapi }\end{array}$ \\
\hline
\end{tabular}




\begin{tabular}{|c|c|c|}
\hline Shot & Dialog/suara/teks & Visual \\
\hline \multirow[t]{3}{*}{$\begin{array}{l}\text { Medium } \\
\text { Shot }\end{array}$} & 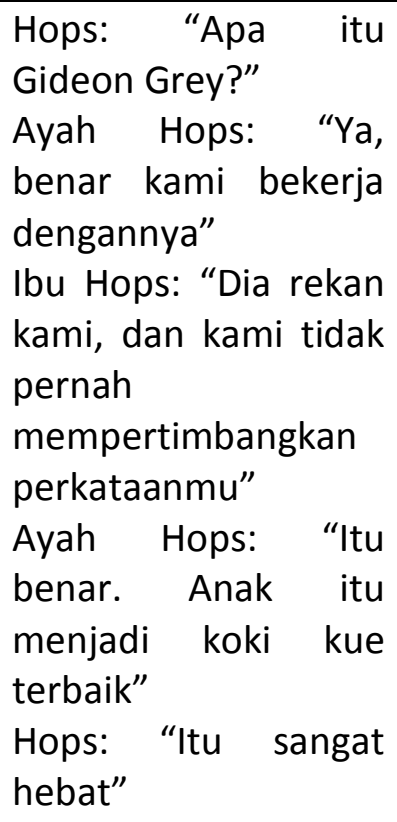 & $\begin{array}{l}\text { Gambar 11. Gideon Grey's datang dengan membawa roti } \\
\text { untuk Hops }\end{array}$ \\
\hline & Penanda & Pertanda \\
\hline & $\begin{array}{l}\text { Gambar Gideon grey } \\
\text { datang di toko } \\
\text { sayuran keluarga } \\
\text { Hops }\end{array}$ & $\begin{array}{l}\text { Gideon Grey yang merupakan musuh hops disaat ia } \\
\text { kecil kini menjadi seorang koki kue terbaik dan } \\
\text { bekerja sama dengan orang tua Hops dalam bisnis } \\
\text { kuenya itu. lbu Hops mengatakan bahwa orang tua } \\
\text { Hops tidak pernah mempertimbangkan apa yang } \\
\text { dikatakan Hops saat jumpa pers ("karena faktor } \\
\text { biologis, hewan predator suatu saat bisa menjadi } \\
\text { liar"). Oleh karenanya orang tua Hops masih } \\
\text { menganggap Gideon Grey adalah saudara dan mitra } \\
\text { dalam bisnis walaupun dia berasal dari jenis hewan } \\
\text { predator }\end{array}$ \\
\hline Shot & Dialog/suara/teks & Visual \\
\hline \multirow[t]{3}{*}{$\begin{array}{l}\text { Medium } \\
\text { Shot }\end{array}$} & $\begin{array}{l}\text { Suara Hops } \\
\text { berpidato: "Buatlah } \\
\text { dunia menjadi lebih } \\
\text { baik, lihatlah ke } \\
\text { dalam dirimu dan } \\
\text { sadari bahwa } \\
\text { perubahan dimulai } \\
\text { dari dirimu, dimulai } \\
\text { dari diriku, dimulai } \\
\text { dari diri kita semua." }\end{array}$ & Gambar 12. Hops dan Nick yang saling hormat \\
\hline & Penanda & Pertanda \\
\hline & $\begin{array}{l}\text { Gambar Hops dan } \\
\text { Nick berpakaian polisi }\end{array}$ & $\begin{array}{l}\text { Petugas Hops menyematkan lencana kepolisian } \\
\text { kepada Nick yang telah berpakaian rapi seragam }\end{array}$ \\
\hline
\end{tabular}




\begin{tabular}{|l|l|l|}
\hline saling berpose & $\begin{array}{l}\text { kepolisian menunjukkan bahwa Nick telah resmi } \\
\text { hormat }\end{array}$ & $\begin{array}{l}\text { kenyandang status polisi Zootopia, kemudian } \\
\text { adegan tersebut, terdengar suara pidato dari Hops } \\
\text { (menyambung dari scene sebelumnya) yang } \\
\text { memberikan pesan untuk membuat dunia lebih baik } \\
\text { dengan bersama-sama dimulai dari diri sendiri }\end{array}$ \\
\hline
\end{tabular}

Tabel 2. Analisis Tataran Kedua Semiotika Roland Barthes

\begin{tabular}{|c|c|}
\hline Penanda & Pertanda \\
\hline $\begin{array}{l}\text { Gambar 13. Pengukuhan Judy Hops sebagai } \\
\text { polisi kelinci pertama }\end{array}$ & $\begin{array}{l}\text { Judy Hops yang seekor kelinci dan merupakan } \\
\text { spesies hewan mangsa mendapat lencana } \\
\text { pengukuhan sebagai Polisi Zootopia. Ini seolah } \\
\text { memberikan pesan bahwa setiap hewan itu } \\
\text { berhak menerima penghargaan atas prestasi } \\
\text { yang telah diukirnya, tidak peduli background } \\
\text { asal hewan tersebut. Selain itu dijelaskan } \\
\text { bahwa Juddy Hops merupakan seekor kelinci } \\
\text { pertama yang berhasil menjadi seorang polisi. } \\
\text { Ini menunjukkan bahwa postur kecil dan } \\
\text { berkemampuan dasar lemah tidak berarti } \\
\text { selamanya akan lemah dan tidak bisa } \\
\text { berprestasi. Juddy Hops telah membuktikan } \\
\text { bahwa ketika sebuah cita-cita itu diperjuangkan } \\
\text { dengan keras, maka walaupun berat, cita-cita } \\
\text { itu pun akhirnya berhasil diraih. }\end{array}$ \\
\hline Penanda & Pertanda \\
\hline $\begin{array}{l}\text { Gambar 14. Beberapa jenis hewan keluar } \\
\text { dari kereta api }\end{array}$ & $\begin{array}{l}\text { Kereta api di Zootopia didesain mempunyai } \\
\text { pintu dengan ukuran variatif sesuai dengan } \\
\text { postur para hewan yang hidup di sana. Ini } \\
\text { menunjukkan bahwa siapapun itu, harus } \\
\text { mendapat kenyamanan yang sama di dalam } \\
\text { memanfaatkan fasilitas umum. Ketika sebuah } \\
\text { kota mempunyai warga yang bermacam-macam } \\
\text { jenis, fasilitas umum kota tersebut haruslah bisa } \\
\text { dirasakan manfaatnya oleh warga secara adil. }\end{array}$ \\
\hline Penanda & Pertanda \\
\hline 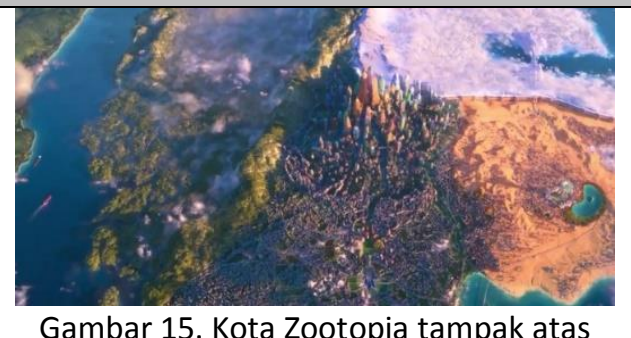 & $\begin{array}{l}\text { Zootopia terbagi dalam } 4 \text { habitat alam yang } \\
\text { berbeda yaitu daerah perkotaan, padang pasir, } \\
\text { daerah es dan daerah pepohonan yang subur } \\
\text { dan rindang. Menunjukkan bahwa Zootopia } \\
\text { memang sebuah tempat yang nyaman untuk } \\
\text { berbagaimacam jenis hewan yang hidup di sana }\end{array}$ \\
\hline
\end{tabular}




\begin{tabular}{|c|c|}
\hline Penanda & Pertanda \\
\hline $\begin{array}{l}\text { Gambar } 16 . \text { Terlihat singa dan jerapah } \\
\text { berdampingan setelah turun dari kereta }\end{array}$ & $\begin{array}{l}\text { Seekor singa yang merupakan hewan pemangsa } \\
\text { dan jerapah yang merupakan hewan mangsa } \\
\text { naik eskalator secara berdampingan di sebuah } \\
\text { stasiun mewah setelah sebelumnya turun dari } \\
\text { kereta. Hal ini memberikan pengertian bahwa } \\
\text { hidup berdampingan antara spesies hewan } \\
\text { pemangsa dan mangsa seolah menjadi hal yang } \\
\text { lumrah di Zootopia, sebuah kota yang maju dan } \\
\text { modern }\end{array}$ \\
\hline Penanda & Pertanda \\
\hline $\begin{array}{l}\text { Gambar 17. Sesi pembagian tugas kepada } \\
\text { para polisi yang berasal dari bermacam- } \\
\text { macam jenis hewan }\end{array}$ & $\begin{array}{l}\text { Para polisi dari spesies yang bermacam-macam } \\
\text { menyambut kepala Bogo yang sedang datang. } \\
\text { Dalam scene ini, ingin menjelaskan bahwa para } \\
\text { petugas polisi yang notabene adalah penangkap } \\
\text { para penjahat/seorang hero, tidak harus berasal } \\
\text { dari spesies pemangsa yang kekar dan gagah. } \\
\text { Asal memenuhi syarat sebagai seorang polisi, } \\
\text { siapapun dan dari jenis hewan apapun, bisa } \\
\text { menjadi seorang polisi/hero yang siap melawan } \\
\text { para musuh }\end{array}$ \\
\hline Penanda & Pertanda \\
\hline $\begin{array}{c}\text { Gambar 18. Hops, Nick, landak dan } \\
\text { sekumpulan sapi yang sedang } \\
\text { menyeberang jalan }\end{array}$ & $\begin{array}{l}\text { Seekor landak yang memiliki bulu tajam, yang } \\
\text { membahayakan bagi hewan sekitarnya } \\
\text { dipersilakan jalan dengan nyaman oleh para } \\
\text { segerombolan sapi, dengan tanpa sedikitpun } \\
\text { mencaci si landak, padahal para sapi berjumlah } \\
\text { jauh lebih banyak dari pada si landak. Ini } \\
\text { menunjukkan betapa sikap toleransi begitu } \\
\text { dijunjung tinggi oleh para penduduk Zootopia. }\end{array}$ \\
\hline Penanda & Pertanda \\
\hline 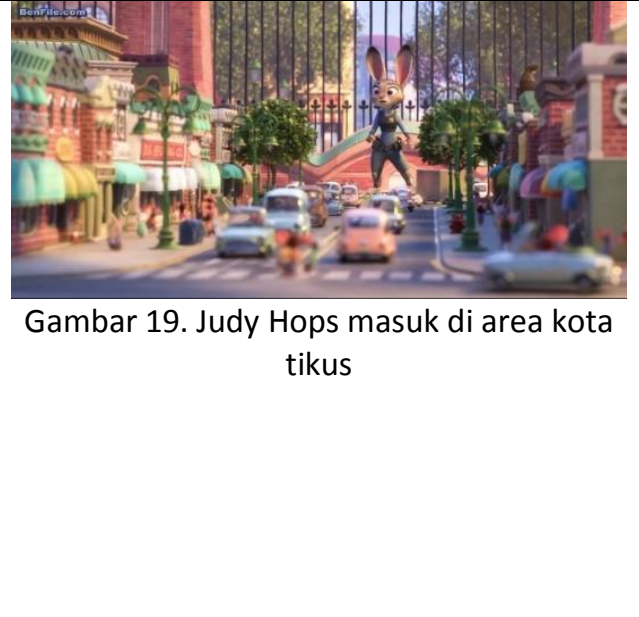 & $\begin{array}{l}\text { Ditengah pengejaran pencuri toko makanan, } \\
\text { hops terkejut karena dia memasuki area } \\
\text { perkampungan tikus yang serba kecil, namun } \\
\text { maju dan damai. } \\
\text { Kehidupan para tikus kecil yang damai, maju } \\
\text { dan modern, ditengah kota hewan-hewan } \\
\text { dengan postur besar, menunjukkan perlakuan } \\
\text { pemerintah yang tidak hanya anti diskriminasi, } \\
\text { tetapi juga tetap memberikan perhatian besar } \\
\text { terhadap perkampungan hewan berpostur kecil, } \\
\text { sehingga menjadi perkampungan yang maju } \\
\text { dan masyarakatnya pun terlihat sejahtera. }\end{array}$ \\
\hline
\end{tabular}




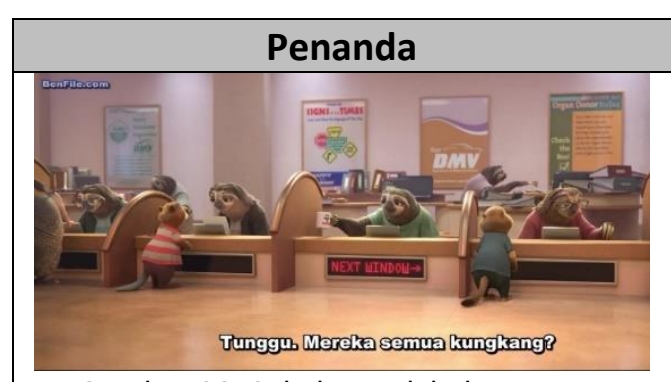

Gambar 20. Sekelompok kukang yang sedang bekerja di DMV sebuah departemen kepengurusan mobil mamalia

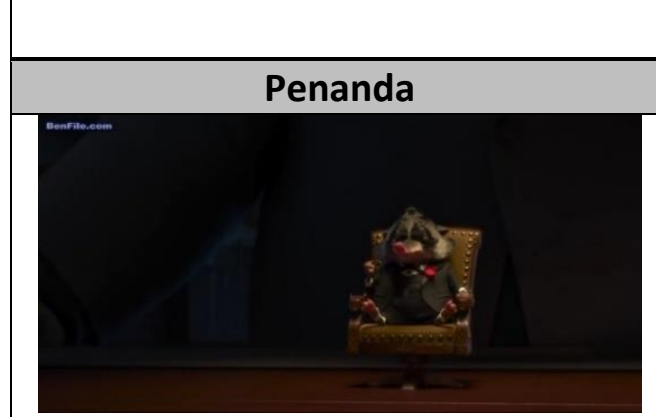

Gambar 21. Mr. Big (bangsa tikus), bos penjahat paling ditakuti di Tundratown

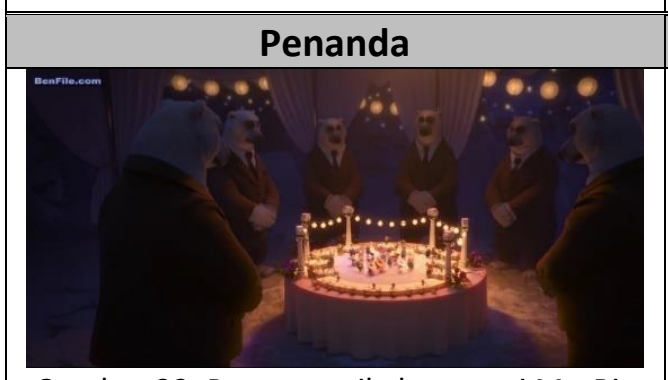

Gambar 22. Pesta pernikahan putri Mr. Big yang diawasi para pengawalnya beruang kutub

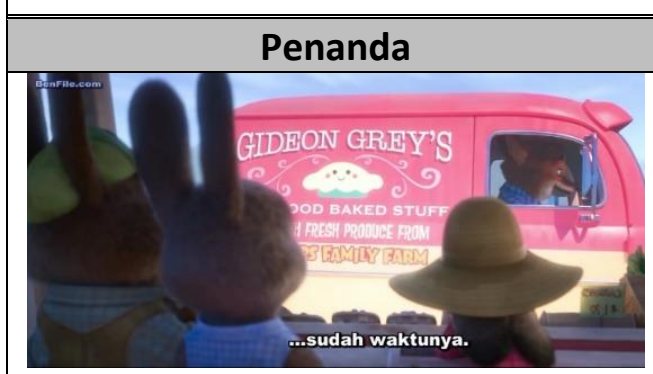

Gambar 23. Gideon Grey's datang dengan membawa roti untuk Hops

\section{Pertanda}

Seluruh pegawai DMV adalah kukang.

Menunjukkan bahwa pemerintah Zootopia sama sekali tidak pilih kasih terhadap seluruh rakyatnya, sampai-sampai spesies kukang yang terkenal pemalas dan lambat bekerja pun, tetap diperkerjakan di DMV. Bahkan para customer juga bisa memahami kondisi tersebut yang terlihat dari ekspresi customer yang tetap sabar, walau dilayani dengan pelayanan yang amat lambat

\section{Seekor tikus kecil bernama Mr. Big, merupakan} bos penjahat paling ditakuti di Tundratown.

Pesan anti diskriminasi di sini sangat kuat, dimana masalah fisik si tikus yang kecil begitu sangat diabaikan, ini terlihat pada nama si tikus yang bernama Mr. Big (Besar). "Big" di sini ternyata merepresentasikan tentang besarnya wibawa dan kekuasaan si tikus, hingga ditakuti seluruh penjahat di Tundratown.

Pertanda

Anak buah Mr. Big dengan patuh menjaga pesta pernikahan anak bosnya. Anak buah Mr. Big yang merupakan Beruang Kutub yang gagah dan terlihat menakutkan begitu patuh dengan bosnya yang seekor tikus kecil. Mereka patuh karena melihat posisi tikus kecil adalah seorang bos dan mereka sebagai seorang anak buah yang harus patuh dan tuntuk dengan bos. Sedikitpun tidak terbersit dibenak para beruang bahwa mereka jauh lebih besar dan kuat, dan tikus adalah hewan kecil dan lemah dan mudah untuk mereka kalahkan

Pertanda

Perkataan Hops saat di TV tentang hewan predator yang suatu saat bisa menjadi liar karena factor biologis sama sekali tidak digubris oleh orang tuanya. Orang tuanya sudah menjalin kerja sama dengan Gideon Greys yang berasal dari jenis hewan pemangsa.

Gideon Greys adalah pembuat roti yang bahan pembuatannya mengambil dari hasil pertanian orang tua Hops, dan kerja sama bisnis mereka lancar. Ini menunjukkan jika dua belah pihak 


\begin{tabular}{|c|l|}
\hline & $\begin{array}{l}\text { yang saling berbeda latar belakang tidak } \\
\text { mempermasalahkan perbedaan dan dapat } \\
\text { bekerja sama, akan menghasilkan hasil positif } \\
\text { dan bahkan memberikan keuntungan bagi } \\
\text { kedua belah pihak seperti yang terjalin antara } \\
\text { Gideon grey dengan orang tua Hops. }\end{array}$ \\
\hline Penanda & \multicolumn{1}{|c|}{ Pertanda } \\
\hline hambar 24. Hops dan Nick yang saling & $\begin{array}{l}\text { Setelah Nick berhasil membantu Hops dalam } \\
\text { menangkap Wakil Walikota yang ternyata } \\
\text { merupakan dalang dari semua kerusuhan yang } \\
\text { terjadi di Zootopia, Nick diangkat menjadi } \\
\text { petugas polisi Zootopia. Mereka saling hormat. } \\
\text { Ini menunjukkan bahwa ketika perbedaan dasar } \\
\text { mereka yang merupakan hewan pemangsa } \\
\text { (Nick) dan hewan mangsa (Hops) tidak begitu } \\
\text { mereka permasalahkan, justru yang mereka } \\
\text { perlihatkan adalah saling bantu satu sama lain } \\
\text { dalam memecahkan suatu masalah yaitu } \\
\text { menangkap dalang dari kekisruhan Zootopia, } \\
\text { akhirnya masalahpun mereka pecahkan dan } \\
\text { derajat mereka menjadi terangkat. }\end{array}$ \\
\hline
\end{tabular}

\subsection{Pembahasan}

Film Zootopia adalah film yang dirilis 4 Maret 2016 yang disutradari oleh Byron Howard. Ini merupakan film animasi fabel yang mengadopsi kehidupan real manusia, dimana layaknya manusia, ada yang bekerja di kantor, pengusaha, polisi, bertani dan aktivitas manusia lainnya.

Film Zootopia ternyata tidak hanya sekedar film yang semata-mata ditujukan untuk hiburan, melainkan banyak pelajaran penting yang terkandung dalam film ini, terutama pelajaran tentang anti diskriminasi sara. Dikisahkan ada seekor anak kelinci bernama Juddy Hops yang bergitu mencita-citakan menjadi seorang polisi, hingga akhirnya dimasa mudanya ia mengikuti tes seleksi fisik kepolisian Zootopia. Berhubung dia hanya seekor kelinci yang memiliki postur yang kecil, pada awalnya dia sempat gagal dan memutuskan untuk pulang. Namun, sesampainya di rumah, dia bukannya putus asa melainkan berlatih sendiri dengan keras dan memutuskan untuk mengikuti tes fisik lagi dan akhirnya berhasil menjadi pelajar polisi terbaik di akademi tersebut dan akhirnya dikukuhkan menjadi seekor polisi dan merupakan polisi pertama dari spesies hewan kelinci. Seperti terlihat pada gambar (1) dimana karena kegigihan dan prestasinya, walaupun hops itu seekor kelinci yang kecil, dia tetap dapat dilantik menjadi seekor kelinci lulusan terbaik akademi polisi Zootopia. Walikota sama sekali tidak mempermasalahkan latar belakang dari Hops tersebut. 
Selanjutnya, ketika hops mau berangkat ke kota Zootopia, ketika kereta datang (Gambar 2) terbukalah pintu kereta dan keluarlah para hewan dengan berbagai macam ukuran postur tubuh. Kereta tersebut yang merupakan alat transportasi umum untuk warga zootopia mempunyai desain pintu dengan ukuran yang bermacam-macam menunjukkan bahwa pemerintah kota menginginkan seluruh hewan yang menaiki kereta tersebut merasakan kenyamanan yang sama, tanpa ada satupun hewan yang merasa tak nyaman karena perbedaan postur tubuh mereka.

Dalam perjalanan kereta menuju kota Zootopia, diperlihatkan kota Zootopia yang terdiri dari 4 habitat (Gambar 3) yaitu perkotaan, gurun pasir, es dan daerah tumbuhan yang lebat. 4 habitat tersebut merupakan habitat yang dibutuhkan bermacam-macam jenis hewan untuk dapat hidup dengan damai nyaman.

Sesaimpainya di stasiun, diperlihatkan sebuah stasiun yang mewah dan modern yang mana didalamnya terdapat bermacam hewan, baik antara hewan pemangsa atau hewan mangsa yang bisa berjalan saling berdampingan, seperti hewan singa dan jerapah yang tampak dalam gambar (4) tersebut. Ini menunjukkan Zootopia adalah sebuah kota yang sangat menjunjung tinggi anti diskriminasi dengan sama sekali tidak mempermasalahkan perbedaan SARA.

Di saat pembagian tugas kepolisian di kantor polisi Zootopia (Gambar 5) terlihat sekumpulan polisi yang berasal dari latar belakang jenis hewan yang berbeda, menunjukkan bahwa siapaun dan dari marga apapun hewan itu, asalkan memenuhi syarat sebagai seorang polisi, dia bisa diterima menjadi anggota polisi Zootopia.

Ditengah-tengah menjalankan tugas, Hops bertemu dengan seekor rubah yang cerdik, namun agak curang dalam mencari uang. Ditengah pembicaraan mereka, mereka bertemu dengan seekor landak yang berbulu tajam menyeberang jalan dan berpapasan dengan segerombolan sapi (Gambar 6). Landak yang membahayakan karena bulunya yang tajam itu ternyata masih dipersilakan lewat oleh hewan-hewan disekitar landak, termasuk segerombolan sapi yang berjalan berlawanan dengan landak tersebut. Ini menunjukkan betapa toleransi antar hewan begitu dijunjung tinggi di lingkungan kota Zootopia.

Ditengah melaksanakan tugas sebagai seorang tukang parkir, ada toko makanan yang dicuri, lalu hops mengejarnya hingga ia masuk di perkampungan tikus yang berukuran serba mini, namun maju dan damai (Gambar 7). Kehidupan para tikus kecil yang damai, maju dan modern, ditengah kota hewan-hewan dengan postur besar, menunjukkan perlakuan pemerintah yang tidak hanya anti diskriminasi, tetapi juga tetap memberikan perhatian besar terhadap perkampungan hewan berpostur kecil, sehingga menjadi perkampungan yang maju dan masyarakatnya pun terlihat sejahtera.

Setelah menangkap pencuri makan tadi, Hops selanjutnya mendapat tugas untuk mencari emmite otterton selama 2 hari, dia meminta bantuan Nick yang cerdik hingga akhirnya Nick mengajak ke DMV, sebuah departemen kepengurusan mobil, yang ternyata seluruh pegawai DMV adalah kukang yang mempunyai etos kerja lambat 
(Gambar 8). Ini memberikan makna bahwa pemerintah Zootopia sama sekali tidak pilih kasih terhadap seluruh rakyatnya, sampai-sampai spesies kukang yang terkenal pemalas dan lambat bekerja pun, tetap diperkerjakan di DMV. Bahkan para customer juga bisa memahami kondisi tersebut yang terlihat dari ekspresi customer yang tetap sabar, walau dilayani dengan pelayanan yang amat lambat.

Petunjuk pencarian selanjutnya membawa Hops dan Nick bertemu dengan Mr. Big, Seekor tikus kecil yang merupakan bos penjahat paling ditakuti di Tundratown (Gambar 9). Di sini pesan anti diskriminasi di sini sangat kuat, dimana masalah fisik si tikus yang kecil begitu sangat diabaikan, ini terlihat pada nama si tikus yang bernama Mr. Big (Besar). "Big" di sini ternyata merepresentasikan tentang besarnya wibawa dan kekuasaan si tikus, hingga ditakuti seluruh penjahat di Tundratown. Terlebih lagi pada Gambar 10, memperlihatkan bahwa anak buah Mr. Big adalah spesies hewan beruang kutub yang besar dan kekar yang sangat patuh dengan Mr. Big. Mereka patuh karena posisi mereka adalah sebagai anak buah dari Mr. Big yang merupakan bos mereka walaupun berpostur tubuh jauh lebih kecil.

Setelah Hops berhasil menemukan 15 mamalia yang hilang, dia mengeluarkan statement yang kontroversial diamana menganggap seluruh hewan predator, karena faktor biologis, berpotensi menjadi liar. Namun Perkataan Hops sama sekali tidak digubris oleh orang tuanya. Orang tuanya sudah menjalin kerja sama dengan Gideon Greys yang berasal dari jenis hewan pemangsa (Gambar 11). Gideon Greys adalah seorang pembuat roti yang bahan-bahan pembuatannya mengambil dari hasil pertanian orang tua Hops, dan kerja sama bisnis mereka lancer. Ini menunjukkan jika dua belah pihak yang saling berbeda latar belakang tidak mempermasalahkan perbedaan itu dan dapat bekerja sama dengan baik, maka menghasilkan hasil positif dan bahkan memberikan keuntungan bagi kedua belah pihak seperti yang terjalin antara Gideon grey dengan orang tua Hops.

Hops dan Nick akhirnya berhasil memecahkan masalah menangkap dalang dari seluruh kekisruhan Zootopia yaitu wakil walikota Bellwether. Atas keberhasilan Nick membantu Hops dalam menangkap Wakil Walikota, Nick diangkat menjadi petugas polisi Zootopia. Mereka saling hormat. Ini menunjukkan bahwa ketika perbedaan dasar mereka yang merupakan hewan pemangsa (Nick) dan hewan mangsa (Hops) tidak begitu mereka permasalahkan, justru yang mereka perlihatkan adalah saling bantumembantu satu sama lain dalam memecahkan suatu masalah yaitu menangkap dalang dari kekisruhan Zootopia, akhirnya masalahpun mereka pecahkan dan derajat mereka menjadi terangkat.

\section{KESIMPULAN}

Film Zootopia merupakan film animasi fabel yang semula ditujukan untuk anak-anak. Namun, dengan balutan cerita, pesan dan proses animasi yang sangat menarik, membuat film ini menjadi cocok dan layak ditonton oleh orang dewasa. Selain keunikan cerita dan penggarapan animasi yang maksimal sehingga grafis dan gerakan animasinya yang bagus, ternyata film ini juga mempunyai makna dan pesan-pesan yang menarik terutama tentang anti diskriminasi SARA. Banyak adegan menunjukkan 
bahwa film ini memang memiliki unsur ideologi yang hendak disampaikan kepada penonton. Seperti dalam fungsi komunikasi massa, salah satunya adalah untuk memberi pengaruh kepada khalayak maka film ini juga memiliki maksud ke sana. Sang sutradara nampaknya berhasil membalut pesan yang ingin disampaikan menjadi sangat menarik.

Walaupun dalam film tersebut seluruh penokohan disajikan dalam bentuk karakter hewan, namun pada dasarnya pesan ideologi yang disampaikan dalam film tersebut adalah ditujukan untuk manusia. Hal ini terlihat pada penokohan hewan yang memerankan profesi dan aktivitas manusia seperti penokohan hewan yang berperan sebagai polisi, tukang parkir, pengusaha, pekerja kantor, pedagang, beraktivitas menggunakan mobil, kereta dan jenis aktivitas dan profesi manusia lainnya.

Pesan ideologi yang ditanamkan dalam film tersebut adalah bahwasannya kedudukan manusia dimata manusia yang lain pada hakikatnya adalah sama. Setiap manusia berhak dan wajib memperlakukan dan diperlakukan secara bijak tanpa memperdulikan background asal manusia itu sendiri. Penghargaan pada setiap individu tidak didasarkan pada faktor keturunan, ras, suku ataupun agama, namun didasarkan pada prestasi dari individu itu sendiri.

\section{DAFTAR PUSTAKA}

Duffy, K.G., Wong, F.Y. 1996. Community Psychology. Boston: Allyn \& Bacon.

Kasali, Rhenald. 2007. Manajemen Periklanan Konsep dan Aplikasi. Jakarta: Pustaka Utama Grafiti.

Kurniawan. 2001. Semiologi Roland Barthes. Mangelang: Indonesiatera.

Piliang, Yasraf Amir. 2004. "Metode Penelitian Desain: Berbagai Kecenderungan Masa Kini". Jurnal Seni Rupa dan Desain, FSRD Untar Jakarta VI/2

Putra, Dedy Kusuma. 2014. Representasi Perempuan Dewasa Yang Terbelenggu Dalam Tayangan Iklan Televisi. Universitas Atma Jaya Yogyakarta.

Marcel, Danesi. 2010. Pesan, tanda dan Makna, Buku Teks Dasar Mengenai Semiotika dan Teori Komunikasi. Yogyakarta: Jalasutra.

Sasongko G., Setiawan. 2005. Kartun Sebagai media Dakwah. Jakarta: Sigma Digi Media.

Sinaga, E.C., Wiranata, I Made, Dewi, P.R.K., 2014. Upaya Uni Eropa dalam Mempromosikan Integrasi Sosial Etnis Roma Di Rumania (2010-2014). Bali.

Sugiyono. 2005. Metode Penelitian Administrasi. Bandung: Alfabeta.

Sutanto, T. 2005. "Sekitar Dunia Desain Grafis / Komunikasi Visual". Pura-pura Jurnal DKV ITB Bandung. 2/Juli

Tinarbuko, Sumbo. 2001. "Semiotika Desain Dagadu Djokdja". Yogyakarta: Dagadu For Beginers Pakuningratan.

Vera, Nawiroh. 2014. Semiotika dalam Riset Komunikasi. Bogor: Galia Indonesia. http://www.bbc.com/indonesia/dunia/2015/05/150501_polisi_temuan_baltimore http://bahasa.kemdiknas.go.id/kbbi/ diakses pada 28 Juli 2016

http://news.okezone.com/read/2015/10/19/337/1234077/setahun-rezim-jokowi-jkmeletus-100-kasus-sara 